\title{
REVIEW OF THE "TATAR-RUSSIAN-LATIN EXPLANATORY DICTIONARY OF IKHTHIONYMS” BY O. N. GALIMOVA (KAZAN: TLAAI, 2019. - 204 P.)
}

\author{
Elvira Irfatovna Safina, \\ G. Ibragimov Institute of Language, Literature and Art, \\ Academy of Sciences of the Republic of Tatarstan, \\ 12 K. Marx Str., Kazan, 420111, Russian Federation, \\ 7idillia@mail.ru.
}

\begin{abstract}
The article reviews the Tatar-Russian-Latin Explanatory Dictionary of fish names ("Balyk atamalarynyn Tatar-Rus-Latin aylatmaly suzlege" = "Tatar-Russian-Latin Explanatory Dictionary of Ichthyonyms") by O. Galimova.

The dictionary contains more than 1800 fish names in the Tatar language and their interpretation, next to each term a translation into Russian and a generally accepted scientific term in Latin are given. The terminological dictionary will be useful to biologists, school teachers, a wide range of practitioners in fisheries, as well as to specialists interested in environmental issues, protection and rational use of aquatic biological resources. The article provides information about the structure of the dictionary, various examples from the dictionary and new ichthyonyms proposed by the author.
\end{abstract}

Key words: ichthyonym, lexicography, dictionaries of the Tatar language, vocabulary, terminology, lexicology.

The emergence of the first Tatar terminological dictionaries is related to Kayum Nasiri's activities. The publication of his works - the dictionary "Istiliyakhate Zhagrafiya" in 1890, which contained geographical terms, and the work "Gulzar va Chamanzar, yagni, ulanlek va chachaklek" in 1894 - expand the horizons of Tatar terminology, attracting scholars' attention to this field of science. With the establishment of the Scientific Center in Kazan in 1920 and the "Commission for the Implementation of the Tatar Language" within, the number of publications of such dictionaries considerably increased, and the collection and systematization of terminology in various fields of science became a topical issue. As a result, dictionaries that contained terms, related to such sciences as mathematics, physics, chemistry, jurisprudence, agriculture, etc. were printed and they made a significant contribution to the development of Tatar terminology. As for recent times, the mass publication of terminological dictionaries dates back to the 1960s and 1980s, especially the $1990 \mathrm{~s}$, and early $21^{\text {st }}$ century.

Today, there are about 30 scholarly dictionaries in Tatar lexicography. Dictionaries of bird names, fish names, and plant names have been added to this list in recent years. The fact that they, like the first dictionaries compiled by K. Nasyri, are related to nature and biology shows that this type of vocabulary is in particular demand.
The reviewed dictionary provides a complete and accurate explanation of each fish, indicating the generally accepted variants of Russian and Latin fish terms used in the Tatar language. Taking into account the fact that our ancestors used to fish, that fish farming is a fast-growing area of food production today, that many ichthyonyms have not been translated into Tatar yet, the compilation of such a dictionary is very timely.

The dictionary contains information about the terms from school textbooks and scientific literature, about fish, living in the waters of Tatarstan and Russia, and includes the terms of ocean and sea fish found in ichthyologic literature, as well as exotic species used by seafood masters.

The work is based on rich lexical material from scientific works on the Tatar language, different types of dictionaries and the studies of fishing terms. The dictionary summarizes 168 groups and lists the names of 1459 ichthyonyms, 166 dialectal ichthyonyms and 485 classifications (tribe, family, detachment, class) in the Tatar language, giving them in the alphabetical order. In order to provide complete information about the fish, the entry states the fish tribe, its habitat, color, and shape, its size and the status of acclimatization and conservation.

The Dictionary of Ichthonyms places great emphasis on the terms of classification, including their construction. Various meanings of the word 
are given separately, stating if the suffixes -лар/ләр (-нар/-нәр) are added to the species names, if the word balyklar is added to the family names, if the terms can be coined according to the same order, or the tribe and family terms are matched.

The main part of the dictionary provides explanations of ichthyonyms, their Russian and Latin versions and classification terms. The main part is followed by an alphabetical list of Russianlanguage terms and proverbs that include fish terms.

The entry of the terms is structured as follows: first comes the main term, then the class, detachment and family; tribal terms, related to the main term, are given in the alphabetic order. For example:

(Gadi) korban balyk BREAM (ORDINARY) Abramis brama from the Carp family; living in many parts of European waters, in the waters of Siberia and the Caucasus, with gray skin, golden brown sides and a yellowish belly; an object of hunting; dial. Ak balyk, daran chabak (maymychlary), lach, lish, luzha, lush ak kuzle korban balygy k. Akkuz.

Amur ak korban balygy BREAM, AMUR WHITE, Parabramis pekinensis from the Carp family; a fish living in the waters from the Amur waters to South China, weighing up to four kilograms, with yellow skin, a silver belly; an object of breeding [p. 74].

Fish terms, used only in the dialects of the Tatar language, are marked with the sign dial. (dialectism). For example:

Kushbash CHUB Leueiscus cephalus --- dial. muklits, chabatabash [p. 79].

Some fish may have about 20 dialectal variants. For example, the following synonyms are found in the Tatar language for the term et balygy (viun, piskun): arysh balygy, zhylan balygy, zhylan balyk, zhylan etlaye, zhyltay, zhyrnay, balyltai, yylan balygy, yylan balyk, mayma balyk, mazhyi, atekach, atem, etlach balygy, etbalyk, etli, etli balyk, etluch, etmay, etanay, yaltyr balyk [p. 154]; variants of the term maymych in different accents: aldauka, balyk chagalary, bukkorsak, vak balyk, zanglay, kerka, kom melese, kos, kugal, mayma, mayma balyk, maymuch, mal, mele, meletke, chabatabash maymuch, maluk, milek, moima, molo, molde, molok, moray balygy, myzhyk, pakarach, pechtor, pioner, serde, syr, tashbash, urlay balyk, chordy, shakalay [p. 88].

Literary language synonyms are given in the alphabetical order and more often are marked with the letter $k$. (see) next to the main term; in rare cases they are placed next to their counterpart: orchykbalyk $k$. sevryuga [p. 101], ranchu $k$. aryslaanbash [p. 109], ukbash $k$. sevryuga, ukboryn $k$. sevryuga [p. 136], etc.

The dictionary also includes the terms that have not been used in the Tatar language so far and are suggested by the author. To distinguish them, they are marked with the sign $(*)$ : yrzhyktesh * scalozub, pavlinkuz * pavlinoglaz, callistus * callistus, mikizha* mikizha, etc.

The terms, related to the classification of fish, will always be an important material to use in dictionaries, by biologists and textbook compilers as the dictionary provides a complete explanation of the names of family, tribe, and detachment. For example, family names:

Dingez chabaklary KORYUSHKOVYYE (SMELT) 1) Osmetridae from the squad of smelt; $A$ family of silver-billed long-tailed fish living in the Atlantic, Pacific and North Pacific basins; objects of hunting; 2) KORYUSHKI (SMELT) Osmerus is a species of small fish families that live in the Atlantic, Pacific and North Pacific Ocean basins; this term unites species of smelt living in European and Asian seas [p. 146];

Irenlach balyklar GUBANOVYE from the squad of trout, a family of long-bodied, thickmouthed, large-scaled, light-colored fish [p. 63];

tribal names:

Zheple balyklar RYBY NITENOSTSY Ctenops from the squad of Labyrinth fish; a species of fish which belly fins are like threads; an aquarium object [p. 59].

At the end of the dictionary, proverbs, including fish names, are given. There are such proverbs among them as tymyzyk kuldo taban yatar (a bream lurked in a quiet lake); horkem uz zhayyn karyi - zhayen do lainy karyi (everyone chooses what he likes, as for catfish, it chooses silt); churtan - tironda soltan (pike is the queen of the depth); yar zhimerelsa, zhoyen ula (if the shore collapses, the catfish will die); vak balyklar arasynda yezgan chabaklar tugel (roach does not swim among small fish).

In conclusion, it should be noted that the vocabulary is rich in lexical material. The selected terms are highly researched and systematized. This dictionary, which provides extensive information about fish, will serve as a useful reference book for biologists, ichthyologists, conservationists, compilers of dictionaries, translators, radio and television reporters, press staff, teachers and general public. 


\title{
ФИЛОЛОГИЯ ФӘННӘРЕ КАНДИДАТЫ ОЛЬГА НИКОЛАЕВНА ГАЛИМОВАНЫН «БАЛЫК АТАМАЛАРЫНЫН ТАТАРЧА-РУСЧА- ЛАТИНЧА АНЛАТМАЛЫ СУЗЛЕГЕ»НӘ (2019) БӘЯЛӘМӘ
}

\author{
Эльвира Ирфат кызы Сафина, \\ ТР ФАнең Г.Ибраһимов исем. Тел, әдәбият һәм сәнгать институты, \\ Россия, 420111, Казан ш., К.Маркс ур., 12 нче йорт,
}

7idillia@mail.ru.

\begin{abstract}
Бәяләмәдә филология фәннәре кандидаты О.Н. Галимованың «Балык атамаларының татарча-русча-латинча аңлатмалы сүзлеге»нә анализ ясала. Сүзлектә 1800 дән артык татар ихтионимнарына аңлатмалар китерелгән, терминнарның рус һәм латин телләрендәге гомум кабул ителгән вариантлары бирелгән. Аңлатмалар һәр балыкның семьялыгы, яшәү ареалы, төсе, зурлыгы күрсәтелгән тулы мәгълүматтан гыйбарәт. Өстәмә белешмә буларак, кайбер балыкларның промыселда әһәмияте, аквариумда үстерелү, үрчетү мөмкинлеге, акклиматизацияләнү, саклану статусы да күрсәтелгән. Авторның балык атамаларын күпьеллык фәнни өйрәнү-тикшеренүләренең нәтижәсе булган әлеге хезмәт татар телендә кулланыла торган барлык ихтионимнарны системага салып, бер урында туплаган чыганак буларак кыйммәтле. Бәяләмәдә сүзлекнең структурасы, төзелеше турында мәгълүмат һәм сүзлектән мисаллар китерелә.
\end{abstract}

Төп төшенчәләр: ихтионим, лексикография, татар теле сүзлекләре, лексика, терминология, лексикология.

Татарча беренче терминологик сүзлекләрнең дөньяга килүе К. Насыйри эшчәнлеге белән бәйләнгән. Галимнең 1890 елда география терминнарын туплаган «Истиляхате жәгърәфия» сүзлеге, 1894 елда «Гөлзар вә чәмәнзар, ягъни үләнлек вә чәчәклек» хезмәтләре басылып чыгу татар терминологиясенең офыкларын киңәйтеп жибәрә, белгечләрнең бу өлкәгә игътибарын арттыра. 1920 нче елда Казанда гыйльми үзәк оешып, аның каршында «Татар телен гамәлгә ашыру комиссиясе» эшчәнлеге башлангач, мондый төр сүзлекләр бастыру аеруча активлашып китә, төрле өлкәләргә караган терминологияне туплау, системага салу эше көнүзәк мәсьәләгә әйләнә. Нәтижәдә, математика, физика, химия, юриспруденция, авыл хужалыгы һ.б. фәннәргә кагылышлы терминнарны туплаган сүзлекләр дөнья күрә һәм алар татар терминологиясе үсешенә сизелерлек өлеш кертә. Яңарак чорларны алганда, терминологик сүзлекләр күпләп басылу XX гасырның 60-80 нче еллары, аеруча 90 нчы еллар həм XXI гасыр башына туры килә.

Бүгенге көндә татар лексикографиясендә фәнни юнәлештәге 30 га якын сүзлек бар. Соңгы елларда әлеге исемлеккә бер-бер артлы дөнья күргән кош атамалары, балык атамалары, үсемлек атамалары сүзлекләре дә өстәлде. Аларның да, К. Насыйри төзегән тәүге сүзлекләр кебек, табигать, биология белән бәйле булуы әлеге төр лексиканың аеруча актив кулланылуын күрсәтә.

Бәяләнә торган сүзлек татар телендә кулланылышта булган балык атамаларының рус һәм латин телендәге гомум кабул ителгән вариантларын күрсәтеп, һәр балыкка тулы, төгәл аңлатма бирә. Ата-бабаларыбызның электән балыкчылык белән шөгыльләнүен, бүгенге көндә аквариумда балык үрчетүнең алга китүен həм әлегә кадәр бик күп ихтионимнарның татарчага тәржемәләре булмавын исәпкә алганда, мондый сүзлек бик кирәк иде.

Сүзлектә Татарстан һәм Россия сулыкларында яши торган балыклар һәм мәктәп дәреслекләрендә, фәнни-популяр әдәбиятта очраган терминнар турында гына түгел, ихтиологик әдәбиятта кулланылган океан, диңгез балыклары, аш-су осталары әзерли торган экзотик төрләр турында да мәгълүмат табарга була.

Хезмәт татар теленең төрле тип сүзлекләренə һәм авторның балыкчылык атамаларын өйрәнүгә багышланган фәнни хезмәтендәге бай лексик материалга нигезләнеп эшләнгән. Сүзлектә 168 ояга туплап, алфавит тәртибендә 
татар теленең әдәби телендәге 1459 ихтионим, 166 диалекталь ихтионим həм 485 классификация (ыруг, семьялык, отряд, класс) атамасы китерелгән. Балык турында тулы мәгълүмат бирү максаты белән, аңлатмаларда аларның семьялыгы, яшәү ареалы, төсе, формасы, зурлыгы, промысел балыкларының һәм аквариумда үрчетелә торган балыкларның акклиматизацияләнү, саклану статусы күрсәтелгән.

Ихтионимнар сүзлегендә классификация терминнарына, шул исәптән аларның ясалышына зур игътибар бирелгән. Ыруг атамалары төр исеменә -лар/-ләр (-нар/-нәр) кушымчасы ялганып, семьялык атамалары балыклар сүзе кушылып ясалган, ә терминнар әйтелгән тәртиптә ясала алмый торган аерым очракларда яисә ыруг һәм семьялык атамалары тәңгәл килгәндә, сүзнең төрле мәгънәләре аерым күрсәтелгән.

Сүзлекнең төп өлешендә ихтионимнарның аңлатмалары, рус, латин телендәге вариантлары hәм классификация атамалары китерелгән. Төп өлешеннән соң рус телендәге атамаларның алфавитка салынган исемлеге һәм балык атамалары кергән мәкаль-әйтемнәр урын алган.

Вокабулаларның бирелеше түбәндәгечә: башта төп атама, аннан соң алфавит тәртибендә әлеге атама белән бәйле башка ихтионимнар, класс, отряд, семьялык, ыруг атамалары китерелә. Мәсәлән:

(гади) корбан балык ЛЕЩ (ОБЫКНОВЕННЫЙ) Abramis brama Карп балыклар семьялыгыннан; Европаның күп кенә сулыкларында, Себер, Кавказ сулыкларында яшәүче, сырты соры, ян-яклары алтынсу коңгырт, корсагы саргыл төстәге балык; ау объекты; диал. ак балык, даран чабак (маймычлары), ләч, лиш, лүжә, лүш, ак күзле корбан балыгы $\kappa$. аккүз.

амур ак корбан балыгы ЛЕЩ АМУРСКИЙ БЕЛЫЙ Parabramis pekinensis Карп балыклар семьялыгыннан; Амур бассейныннан алып, Көньяк Кытайга кадәрге сулыкларда яшәүче, сырты яшькелт, корсагы көмешсу төстәге дүрт кг га кадәр авырлыктагы балык; үрчетү объекты [74 б.].

Татар теленең диалектларында гына кулланыла торган балык атамалары диал. (диалектизм) тамгасы белән аерып күрсәтелгән. Мисал өчен:

кушбаш ГОЛАВЛЬ Leueiscus cephalus диал. мүклиц, чабатабаш [79 б.]. Кайбер балыкларның 20 гә якын диалекталь варианты булырга мөмкин. Мәсәлән, эт балыгы (вьюн, пискун) атамасының татар теле сөйләшләрендә түбәндәге синонимнары очрый: арыш балыгы, жылан балыгы, жылан балык, жылан этләе, жылтай, жырнай, йылан балыгы, йылан балык, майма балык, мыжый, этекәч, этем, этләч балыгы, этбалык, этли, этли балык, этлүч, этмәй, этәнәй, ялтыр балык [154 б.], маймыч атамасының сөйләшләрдәге вариантлары: алдаука, балык чагалары, буккорсак, вак балык, зәңгләй, керкә, ком мелесе, көс, кугал, майма, майма балык, маймуч, мал, меле, мелетке, чабатабаш мәймүч, мәлүк, милек, мойма, мөлө, мөлде, мөлөк, мөрәй балыгы, мыжык, пакарач, печтәр, пионер, серде, сыр, ташбаш, үрләү балык, чорды, шәкәләй [88 б.].

Әдәби телдәге синоним атамалар алфавит тәртибендә үз урынында бирелгән һәм ешрак беренчесенә - төп атамага $\kappa$. (карагыз) тамгасы белән жибәрелгән, сирәк очракларда тиңдәше янында өтер аша күрсәтелгән: орчыкбалык $\kappa$. севрюга [101 б.], ранчу $к$. арысланбаш [109 б.], укбаш $\kappa$. севрюга, укборын $\kappa$. севрюга [136 б.] h.б.

Сүзлектә татар телендә әле моңарчы кулланылмаган, автор тәкъдим иткән атамалар да очрый. Аерылып торсын өчен алар йолдыз (*) тамгасы белән бирелгән: ыржыктеш* скалозуб, павлинкүз* павлиноглаз, каллистус* каллистус, микижа* микижа h.б.

Хезмәттәге балыкларның классификациясе белән бәйле терминнар сүзлекчеләр, биологлар, дәреслек төзүчеләр өчен һәрдаим файдаланырлык мөһим материал булып торачак. Семьялык, ыруг, отряд исемнәренә шактый тулы аңлатма китерелгән. Мисал өчен, семьялык исемнәре: диңгез чабаклары КОРЮШКОВЫЕ 1) Osmetridae Диңгез чабагысыманнар отрядыннан; Атлантик, Тын, Төньяк Боз океаны бассейннарында очраучы көмешсу төстәге озынча гәүдәле балыклар семьялыгы; ау объекты; 2) КОРЮШКИ Osmerus Диңгез чабаклары семьялыгыннан, Атлантика, Тын, Төньяк Боз океаны бассейнында яшәүче зур булмаган балыклар ыругы; Европа, Азия диңгез чабакларын һ.б. төрләрне берләштерә [146 б. $]$; иренләч балыклар ГУБАНОВЫЕ Алабугасыманнар отрядыннан, озынча гәүдәле, калын иренле, эре тәңкәле ачык төсле балыклар семьялыгы [63 б.]; ыруг исемнәре: жепле балыклар РЫБЫНИТЕНОСЦЫ Ctenops Лабиринт балыклар асотрядыннан; корсак йөзгечләре жеп кебек булган балыклар ыругы; аквариумчылык объекты [59 б.]. 
Сүзлек ахырында балыклар турында мәкаль-әйтемнәр китерелгән. Алар арасында тымызык күлдә табан ятар; һәркем Үз жсаен карый - ж⿻әен дә лайны карый; чуртан тирәндә солтан; яр жсимерелсә, жсәен үлә; вак балыклар арасында йөзгән чабаклар түгел без арасында кебек вариантлар бар.

Нәтижә ясап, шуны билгеләп үтәргә кирәк: сүзлек лексик материалының бай булуы белән аерылып тора. Сайлап алынган терминнар югары дәрәжәдә тикшерелгән һәм системага салынган. Балыклар турында бай мәгълүмат бирә торган әлеге сүзлек биологлар, ихтиологлар, табигатьне саклаучылар, сүзлекчеләр, тәржемәчеләр, радио һәм телевидение, матбугат хезмәткәрләре, укытучылар һәм, гомумән, киң катлам укучылар өчен файдалы белешмә булып хезмәт итәчәк.

\title{
РЕЦЕНЗИЯ НА «ТАТАРСКО-РУССКО-ЛАТИНСКИЙ ТОЛКОВЫЙ СЛОВАРЬ ИХТИОНИМОВ» О.Н.ГАЛИМОВОЙ (КАЗАН: ТӘһСИ, 2019. - 204 Б.)
}

\author{
Эльвира Ирфатовна Сафина, \\ Институт языка, литературы и искусства АН РТ, \\ Россия, 420111, г. Казань, ул. К.Маркса, д. 12, \\ 7idillia@mail.ru.
}

В рецензии дана оценка татарско-русско-латинскому толковому словарю названий рыб («Балык атамаларының татарча-русча-латинча аңлатмалы сүзлеге» = «Татарско-руссколатинский толковый словарь ихтионимов») О.Н.Галимовой.

Словарь содержит более 1800 названий рыб на татарском языке и их толкования, рядом с каждым термином дается перевод на русский язык и общепринятый научный термин на латинском языке. Терминологический словарь будет полезен биологам, учителям школ, широкому кругу практических работников рыбного хозяйства, а также специалистам, интересующимся вопросами экологии, охраны и рационального использования водных биологических ресурсов. В статье приводятся сведения о структуре, строении словаря и различные примеры из словаря, новые ихтионимы, предложенные автором.

Ключевые слова: ихтионим, лексикография, словари татарского языка, лексика, терминология, лексикология. 